\title{
COVALENT ATTACHMENT OF PHENYL AND CARBOXYPHENYL LAYERS DERIVED FROM DIAZONIUM SALTS ONTO ACTIVATED CHARCOAL FOR THE ADSORPTION OF PESTICIDES
}

\author{
Jeton Halili, Fexhrie Salihu, Avni Berisha* \\ Chemistry Department of Natural Sciences, University of Prishtina "Hasan Prishtina", \\ Str. Nëna Terezë 5, 10000 Prishtina, Kosovo \\ avni.berisha@uni-pr.edu
}

\begin{abstract}
The past and recent uncontrolled use of organochlorine pesticides imposes serious problems due to their adverse undesired effects in ecosystems. Finding new ways to dispose of these molecules is therefore mandatory. The covalent modification of activated charcoal powder (ACP) by substituted aryl groups can be achieved by reaction with aryl radicals obtained through the sonically induced dediazonation of diazonium salts. Seventeen organochlorine pesticides were adsorbed on ACP covalently grafted with phenyl and carboxyphenyl layers. The sorption percentages of the pesticides onto the carboxyphenyl modified ACPs [measured by GC-ECD (Gas Chromatography - Electron Capture Detector)] were in the range of $90-100 \%$ (DDT, $\delta$-HCH, $\gamma-\mathrm{HCH}$ and endrin aldehyde), $80-90 \%$ (methoxychlor, endosulfan II, $p, p-\mathrm{DDD}$ and $\beta-\mathrm{HCH})$ and $60-80 \%(\alpha-\mathrm{HCH}, \mathrm{DDE}$, endosulfansulfate, endrin, endosulfan I, aldrin, heptachlorepoxid, dieldrin and heptachlor). A tentative explanation is given for these differences based on steric effects.
\end{abstract}

Keywords: organochlorine pesticides; adsorption; covalent modification; diazonium salts; grafting

\section{КОВАЛЕНТНО ВРЗУВАЫЕ НА ФЕНИЛНИ И КАРБОКСИФЕНИЛНИ СЛОЕВИ ИЗВЕДЕНИ ОД ДИАЗОНИЈУМ СОЛИ НА АКТИВЕН ЈАГЛЕН ЗА АТСОРПИЦЈА НА ПЕСТИЦИДИ}

\begin{abstract}
Поранешната и неодамнешната неконтролирана употреба на органохлорни пестициди предизвика сериозни проблеми поради нивните несакани ефекти врз екосистемите. Од тие причини задолжително мора да се изнајдат начини за нивно уништување. Ковалентната модификација на прав од активен јаглен (ACP) со супституирани арилни групи може да се постигне со реакција на радикали на арил добиени со сонично индуцирана дедиазонација на диазониум-соли. Беше извршено атсорбирање на седумнаесет органохлорни пестициди на АСP ковалентно накалемен со фенилни и карбоксилни слоеви. Сорпцијата на пестицидите врз карбоксифенилно модифицираните АCP [определни со GC-ECD (гасна хроматографија - детектор со електронски зафат)] беше во опсегот од 90-100\% (DDT, $\delta$-HCH, $\gamma$-HCH и ендрин алдехид), 80$90 \%$ (метоксихлор, ендосулфан II, $p, p$-DDD и $\beta-\mathrm{HCH})$ и 60-80\% ( $\alpha$-HCH, DDE, ендосулфансулфат, ендрин, ендосулфан I, алдрин, хептахлорепоксид, диелдрин и хептахлор). Хипотетичкото објаснување за овие разлики се базира на стерни ефекти.
\end{abstract}

Клучни зборови: органохлорни пестициди; атсорпција; ковалентна модификација; диазониум-соли; калемење

\section{INTRODUUCTION}

The introduction of pesticides into the environment by agricultural applications, spills or accidents significantly influences the wellbeing of eco- systems [1-3] by inducing severe potential toxic effects [4-6]. Although these substances are used and controlled under strict law regulations in developed countries, in many other countries, their use is not well regulated. As a consequence, the 
presence of pesticide residues can be found in consumer products, such as dairy products, fruits, olive oil and vegetables [7]. In addition, even if organochlorine pesticides, which are among the most harmful, are no longer in use, they are still present in important concentrations [1] due to their environmental stability [8]. In epidemiological studies [6], a number of chlorinated pesticides have been associated with elevated incidences of cancer, reproductive disorders, Alzheimer's disease, peripheral arterial diseases and so on. Thus, the degradation of these molecules or their removal from the ecosystem [9] is of great importance for the environment. The degradation of pesticides can be achieved: i) biologically by the use of microorganisms [10], ii) by Fenton-type advanced oxidation processes [9], and iii) by phytoremediation [11], when the volume of polluted soil/water is important. However, these processes suffer from high costs and difficult technological implementation. In addition to degradation processes, pesticides can be removed from polluted waters by membrane processes or through adsorption, which are technologically simple and cost effective $[4,12]$.

The dediazonation of diazonium salts [13$19]$ is a very efficient method for attaching thin organic films to a variety of substrates (conductors, semiconductors and polymers). This reaction can take place by electrochemistry $[13,17,18]$, photochemistry [20] or under ultrasonication [21, 22]. It involves the formation of an aryl radical that reacts with the surface and with the first grafted group, providing a polyphenylene organic film covalently bonded to the surface. As a result of the conjugation, this oligomer is planar, but the different oligomeric chains are likely disordered as no order has ever been evidenced [14-16]. A disordered lamellar structure of substituted aryl groups is formed (Fig. 1) that should be able to trap molecules. Such polyphenylene with cyclams or calixarene structures have already been used for trapping ions $\left(\mathrm{Cu}^{2+}\right.$ and $\left.\mathrm{Pb}^{2+}\right)$ [23-25].

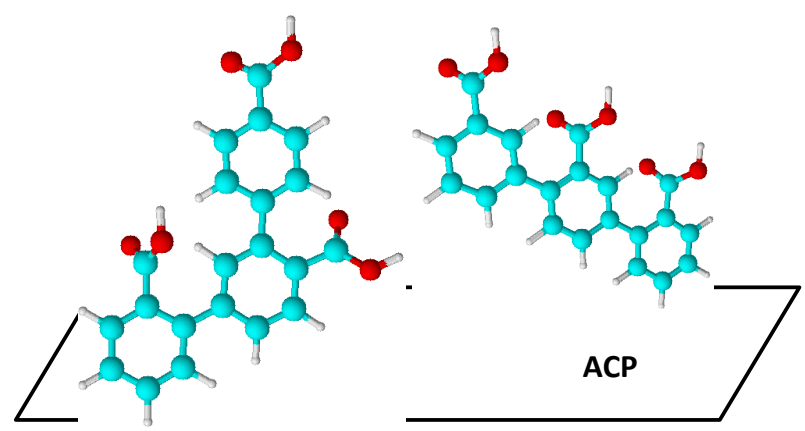

Fig. 1. Schematic presentation of polyphenylene-COOH organic film covalently bonded on the surface of the ACP
Activated charcoal powder (ACP) is a highly porous carbon with micro- and mesopores [24, 26] (typically less than $2 \mathrm{~nm}$ for micropores, $2-50 \mathrm{~nm}$ for mesopores and $>50 \mathrm{~nm}$ macropores) with large specific surface (that can be larger than $500 \mathrm{~m}^{2} \mathrm{~g}^{-1}$ ). Activated carbon cloth or pearls have already been modified by diazonium salt chemistry for adsorption, combinatorial chemistry and supercapacitors $[27,28]$. The structures of these polyaryl modified activated charcoal are therefore extremely complex, but their properties, such as hydrophobicity/hydrophilicity, $\pi-\pi$ stacking or hydrogen bonding capacity, can be tuned by changing the substituents of the aryl group.

In this study, we first check the spontaneous grafting of ACP by diazonium salts and then use this ACP modified with phenyl $\left(\boldsymbol{A C P}-\mathrm{C}_{6} \mathrm{H}_{5}\right)$ and carboxyphenyl $\left(\boldsymbol{A C P}-\mathrm{C}_{6} \mathrm{H}_{4} \mathrm{COOH}\right)$ groups for the adsorption of 17 pesticides from an aqueous or hexane solution.

\section{MATERIALS AND METHODS}

\subsection{Chemicals}

The pesticide standard, EPA Appendix IX Organochlorine Pesticides Mix $(2000 \mu \mathrm{g} / \mathrm{ml}$ each component in hexane : toluene (1:1)), was purchased from Sigma-Aldrich. A stock solution of the pesticide mix was prepared by diluting the proper volume of the standard solution with double distilled chromatographic grade hexane (CHROMASOLV $®)$ to give a solution of concentration. ACP (untreated powder, 100-400 mesh), 4-aminobenzoic acid (ReagentPlus ${ }^{\circledR}, \geq 99 \%$ ), tetrabutylammoniumtetrafluoroborate (for electrochemical analysis, $\geq 99.0 \%$ ), aniline (ACS reagent, $\geq 99.5 \%$ ), acetonitrile (CHROMASOLV® Plus, for HPLC, $\geq 99.9 \%$ ), 4-bromobenzenediazonium and sodium nitrite $(99.999 \%$ trace metals basis) were purchased from Sigma-Aldrich and 4-nitro and 4bromoaniline, hydrochloric acid (30-35\%, TraceSELECT ${ }^{\circledR}$ Ultra) were from Fluka.

\subsection{Apparatus}

The electrochemical study was carried out in deaerated $\mathrm{ACN}+0.1 \mathrm{Bu}_{4} \mathrm{NBF}_{4}$ using a computercontrolled PalmSens potentiostat and employing a three electrode cell assembly. A silver/ $\mathrm{AgCl}$ wire and platinum electrode were used as the reference and auxiliary electrodes, respectively.

IR spectra were taken on a Jasco FT/IR6100 with samples prepared as $\mathrm{KBr}$ pellets. For 
each spectrum, 500 scans were accumulated with a spectral resolution of $4 \mathrm{~cm}^{-1}$.

The elemental analysis was obtained from Institut de Sciences Analytiques (CNRS), Villeurbane, France.

A gas chromatograph (Agilent Technologies $6890 \mathrm{~N}$, Network GC system) equipped with an electron capture detector (ECD), with a capillary column HP-5 $(30.0 \mathrm{~m} \times 250.00 \mu \mathrm{m} \times 0.25 \mu \mathrm{m})$, an injector at $290{ }^{\circ} \mathrm{C}$ and a detector at $320{ }^{\circ} \mathrm{C}$. The operating conditions were a nitrogen carrier gas at $1.0 \mathrm{ml} / \mathrm{min}$. The temperature program was as follows: initial oven temperature $100{ }^{\circ} \mathrm{C}$ hold for 1 min then a $20{ }^{\circ} \mathrm{C} \mathrm{min}{ }^{-1}$ ramp to $150{ }^{\circ} \mathrm{C}$, followed by $6{ }^{\circ} \mathrm{C} \min ^{-1}$ ramp to $300{ }^{\circ} \mathrm{C}$. The splitless injection mode was used with an injection volume of $2.0 \mu 1$. The concentration of the pesticides after adsorption was evaluated by the use of the corresponding calibration curves (see Supporting Information) for each of the pesticides in the standard.

\subsection{Procedure for surface modification of ACP}

A $2 \mathrm{~g}$ sample of ACP was dispersed into 100 $\mathrm{ml}$ of a $5 \mathrm{mM}$ solution of aniline, 4-aminobenzoic acid or 4-bromo or nitroaniline dissolved in $0.5 \mathrm{M}$ hydrochloric acid. Afterwards, a concentrated solution of sodium nitrite was pipetted in this solution, to obtain a final concentration of $5 \mathrm{mM}$ of the diazonium salt. In this mixture containing the diazonium salt, $2 \mathrm{~g}$ of ACP were dispersed and sonicated in for $1 \mathrm{~h}$ (Fig. 2A). The modified ACPs (ACP$\mathrm{C}_{6} \mathrm{H}_{5}, \boldsymbol{A C P}-\mathrm{C}_{6} \mathrm{H}_{4} \mathrm{NO}_{2}, \quad \boldsymbol{A} \boldsymbol{C P}-\mathrm{C}_{6} \mathrm{H}_{4} \mathrm{Br}$ and $\boldsymbol{A} \boldsymbol{C P}$ $\mathrm{C}_{6} \mathrm{H}_{4} \mathrm{COOH}$ ) were filtered, washed with copious amounts of water, re-sonicated in acetonitrile (to remove possible adsorbed oligomers formed during the grafting reaction), washed in filter paper with acetonitrile and dried.

\subsection{Tests for presence of covalently attached layer}

The carbon paste electrode was prepared by thoroughly mixing $1 \mathrm{~g}$ of $\boldsymbol{A C P}-\mathrm{C}_{6} \mathrm{H}_{4} \mathrm{NO}_{2}$ with 0.36 $\mathrm{ml}$ of paraffin oil in a mortar with pestle. The obtained paste was packed into the hole of the electrode body (constructed by pressing a small rod of stainless steel $(d=2 \mathrm{~mm})$ inside a micropipette tip $(1 \mathrm{ml}$ volume $)$ to leave a depression at the tip surface $(\sim 1 \mathrm{~mm})$ for housing the carbon paste and a thin copper wire was inserted through the opposite end to establish electrical contact) and smoothed on a clean Teflon ${ }^{\circledR}$ surface [29].
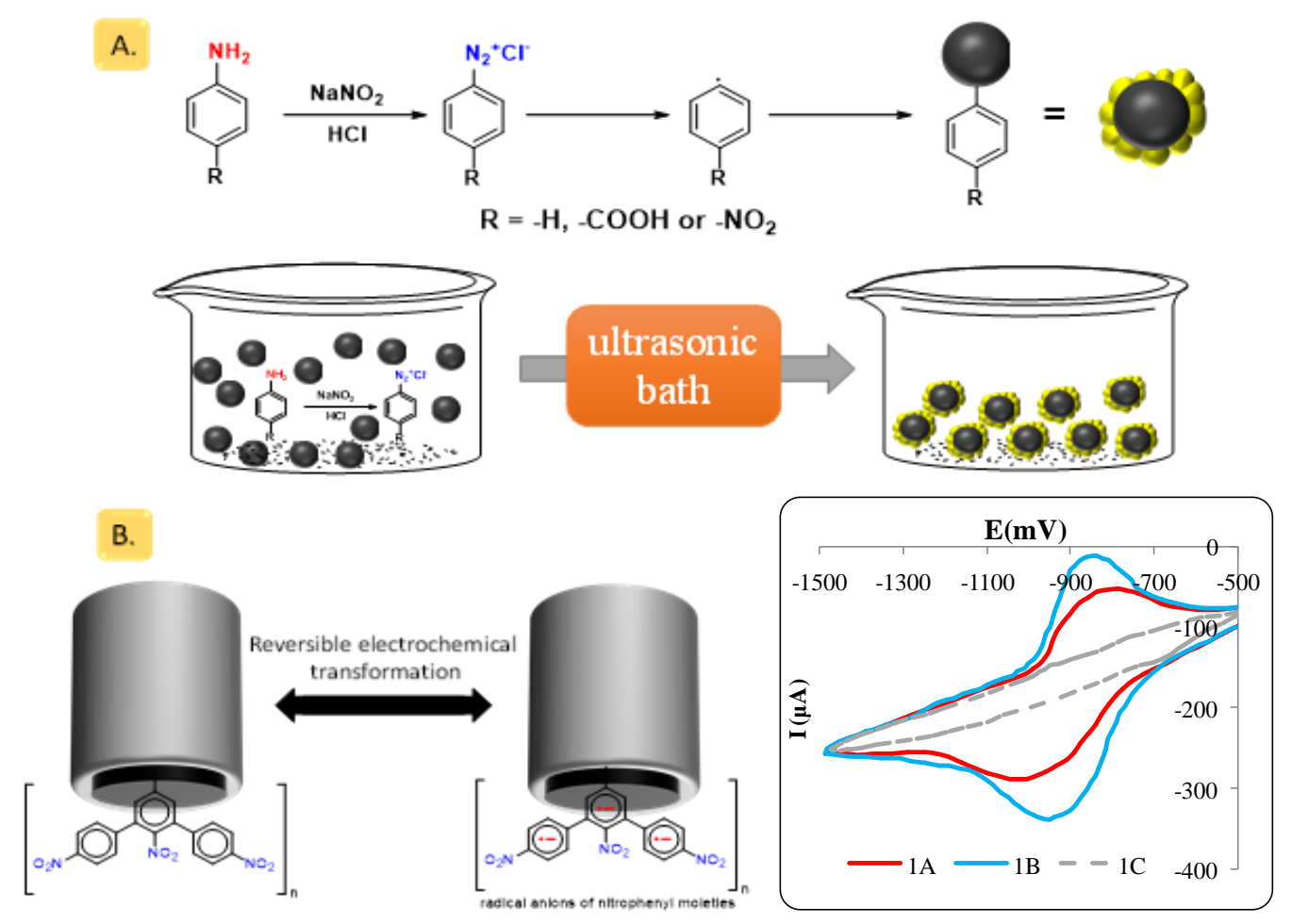

Fig. 2. A. Reaction scheme of "in situ" generation of the different diazonium salts and their attachment to ACP surface.

B. Electrochemical reduction of the covalently attached nitrophenyl moiety and the corresponding cyclic voltammogram of: 1A. carbon paste modified with grafted layers of $-\mathrm{Ph}-\mathrm{NO}_{2}$; 1 B. $2.5 \mathrm{mM}$ solution of 4-nitrobenzene with non-modified carbon paste; 1C. non-modified carbon paste (cyclic voltammograms were recorded in an $\mathrm{ACN}+0.1 \mathrm{M} \mathrm{Bu}_{4} \mathrm{NBF}_{4}$ solution, $v=180 \mathrm{mVs}-1$, ref. $\mathrm{Ag} / \mathrm{AgCl})$. 
The ATR spectra of modified ACP were recorded using a purged (low $\mathrm{CO}_{2}$, dry air) Jasco FT/IR-6100 Fourier transform infrared spectrometer equipped with a mercury-cadmium-telluride detector. For each spectrum, 1000 scans were accumulated with a spectral resolution of $4 \mathrm{~cm}^{-1}$. The background recorded before each spectrum was that of ACP. ATR spectra were recorded with a germanium ATR accessory (Jasco ATR PR0470-H).

\subsection{Adsorption study of pesticides}

The sorption of the pesticides was achieved on ACP according to two different methods, either after extraction from an aqueous solution or directly in a hexane solution. In the first method, $5 \mathrm{mg}$ of $\boldsymbol{A C P}, \boldsymbol{A C P}-\mathrm{C}_{6} \mathrm{H}_{5}$ or $\boldsymbol{A C P}-\mathrm{C}_{6} \mathrm{H}_{4} \mathrm{COOH}$ was suspended in $2 \mathrm{ml}$ of water, before $1 \mathrm{ml}$ hexane was added (final concentration of $250 \mathrm{ppb}$ ). The solution was stirred for $60 \mathrm{~min}$ and then left to settle, and the hexane layer was injected for analysis of the pesticide content. In the second method, the sorption percentage and sorption capacity of the modified ACP in the presence of organochlorine pesticides was obtained by using $3 \mathrm{ml}$ of a hexane solution pesticide solution and adding $5 \mathrm{mg}$ of the corresponding sorbent $\left(\boldsymbol{A C P}-\mathrm{C}_{6} \mathrm{H}_{5}\right.$ or $\boldsymbol{A C P}$ $\mathrm{C}_{6} \mathrm{H}_{4} \mathrm{COOH}$ ) into this solution (final concentration $250 \mathrm{ppb}$ ). After the adsorption, the suspension was filtered and $0.8 \mathrm{ml}$ was then collected into a $1.5 \mathrm{ml}$ vial and further analysed by GC-ECD.

The performance of the GC-ECD method in the detection of pesticides is very satisfactory [30] for all the analysed pesticides. The regression coefficient is almost unity, showing a nearly perfect linearity of the signal with the concentration.

\section{RESULTS AND DISCUSSION}

In order to ascertain the grafting of ACP, it was derivatised with 4-substituted diazonium salts that give characteristic electrochemical or spectroscopic features. $\boldsymbol{A C P}-\mathrm{C}_{6} \mathrm{H}_{4} \mathrm{NO}_{2}$ obtained by reaction of 4-nitrobenzenediazonium was first examined by recording the voltammogram of a carbon paste electrode (prepared as described in the experimental section 2.4). The electrochemical signal from the quasi reversible electrochemical transformation of the nitrophenyl group into its radical anion was tested through cyclic voltammetry by applying a potential sweep to the electrode from -0.4 to $-1.5 \mathrm{~V}$ in deaerated $\mathrm{ACN}+0.1 \mathrm{NBu}_{4} \mathrm{BF}_{4}$ (Figure 2.B. Part B.1A-B.1C). The electrode signal was compared with the signal obtained (in $\mathrm{ACN}+$ $0.1 \mathrm{Bu}_{4} \mathrm{NBF}_{4}$ ) from i) a non-modified ACP and ii) a non-modified ACP in the presence of a $2.5 \mathrm{mM}$ solution of 4-nitrobenzene. The similarity of the voltammograms of nitrobenzene and $\boldsymbol{A C P}$ $\mathrm{C}_{6} \mathrm{H}_{4} \mathrm{NO}_{2}\left(E^{\circ}=-0.85 \mathrm{~V} /(\mathrm{Ag} / \mathrm{AgCl})\right.$ clearly indicates the successful grafting, as with other carbons [13].

The IR spectrum of a) $\boldsymbol{A C P}-\mathrm{C}_{6} \mathrm{H}_{4} \mathrm{COOH}$ is presented in Figure 3 along with that of the b) 4carboxybenzenediazonium tetrafluoroborate. The IR spectrum of the former presents IR absorptions at $1698 \mathrm{~cm}^{-1}(-\mathrm{C}=\mathrm{O}$ stretch$)$ and 1611 and 1584 $\mathrm{cm}^{-1}(-\mathrm{C}=\mathrm{C}$ stretch from aromatic ring) that are also present in the spectrum of the 4-carboxybenzenediazoniumtetrafluoroborate [31]. Furthermore, the absence of the $-\mathrm{N} \equiv \mathrm{N}$ stretch corresponding to the diazonium group in $\boldsymbol{A C P}$ $\mathrm{C}_{6} \mathrm{H}_{4} \mathrm{COOH}$ at $2310.3 \mathrm{~cm}^{-1}$ confirms a successful grafting reaction $[14,15,31]$.

For such powdered materials, it is important to obtain an estimate of the amount of functionalisation. In order to obtain the ratio of number of modified aryl groups:number of ACP carbon atoms, $\boldsymbol{A C P}-\mathrm{C}_{6} \mathrm{H}_{4} \mathrm{Br}$ was prepared as described above. The elemental analysis gave C: $72.16 \%$ and $\mathrm{Br}: 2.96 \%$, which corresponds to 3.8 aryl groups per 100 carbon atoms.

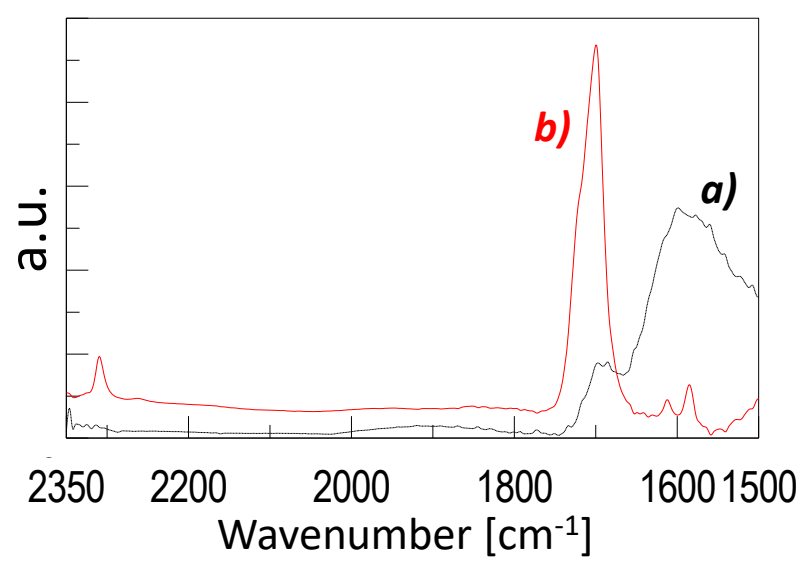

Fig. 3. IR spectra of (a) $\boldsymbol{A C P}-\mathrm{C}_{6} \mathrm{H}_{4} \mathrm{COOH}$ and (b) 4-carboxybenzenediazonium tetrafluoroborate. Normalised spectra arbitrary absorption units

ACP was then modified with phenyl and carboxyphenyl groups, as described above, to give $\boldsymbol{A} \boldsymbol{C P}-\mathrm{C}_{6} \mathrm{H}_{5}$ and $\boldsymbol{A C P}-\mathrm{C}_{6} \mathrm{H}_{4} \mathrm{COOH}$. The hexane solution obtained after sorption of the pesticides or extraction of the aqueous solution (Figs. 4 and 5, respectively) by $\boldsymbol{A C P}-\mathrm{C}_{6} \mathrm{H}_{5}$ and $\boldsymbol{A C P}-\mathrm{C}_{6} \mathrm{H}_{4} \mathrm{COOH}$ were analysed by GC-ECD to quantify the amount of pesticide remaining in solution. The sorption percentage was calculated from Equation 1 and the sorption capacity from Equation 2: 


$$
\begin{gathered}
\text { Sorption } \%=\frac{\text { Cfinal }}{\text { Cinitial }} * 100 \\
q_{e}=\frac{\gamma_{0}-\gamma_{e}}{\mathrm{~m}} V
\end{gathered}
$$

where $\gamma_{0}$ and $\gamma_{\mathrm{e}}$ present the initial and equilibrium concentrations of the solute $\left(\mathrm{mg} \mathrm{l}^{-1}\right)$ in the mixture solution, respectively, $V$ is the volume of the solution (l) and $m$ is the mass of the adsorbent (g).

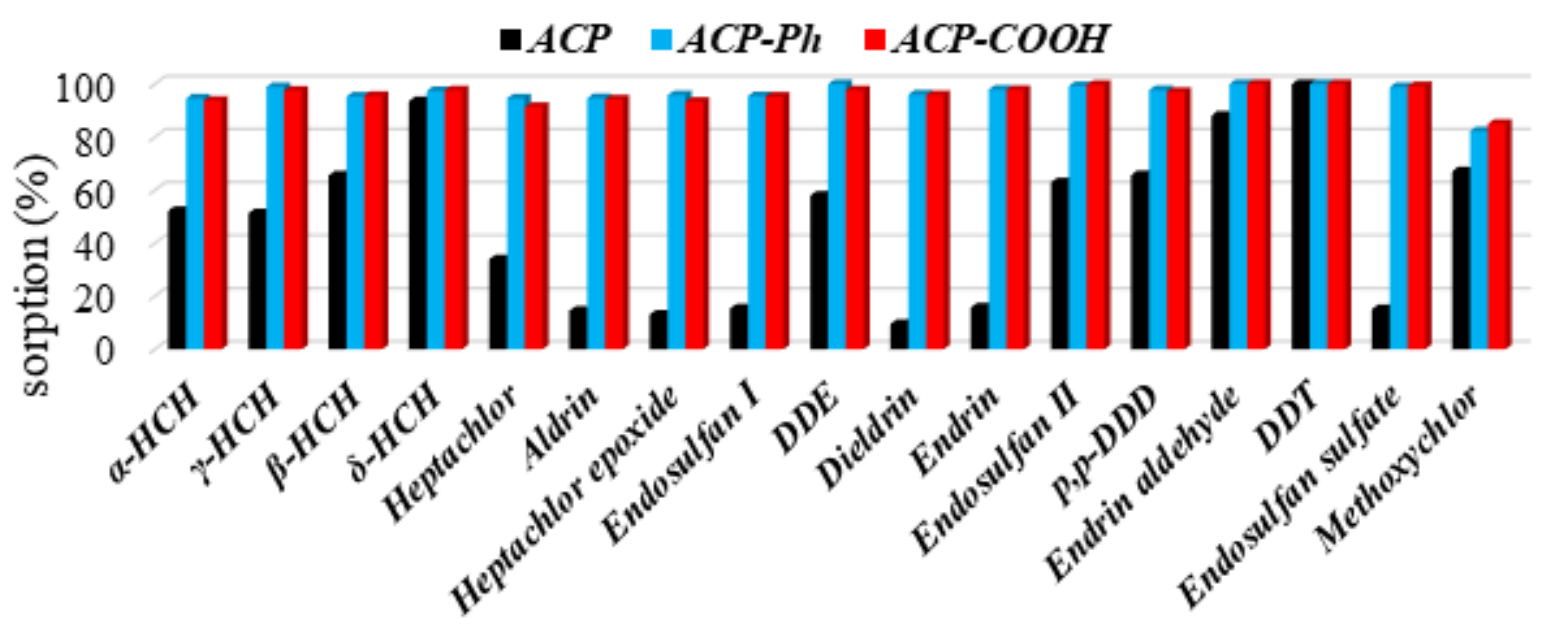

Fig. 4. Sorption percentage of the corresponding pesticides from an aqueous solution extracted with hexane (sorption time of $60 \mathrm{~min}$ ) onto $\mathbf{A C P}, \boldsymbol{A C P}-\mathrm{C}_{6} \mathrm{H}_{4}$ and $\boldsymbol{A C P}-\mathrm{C}_{6} \mathrm{H}_{4}-\mathrm{COOH}$ modified activated carbon. Sorbent mass $=5 \mathrm{mg}$.

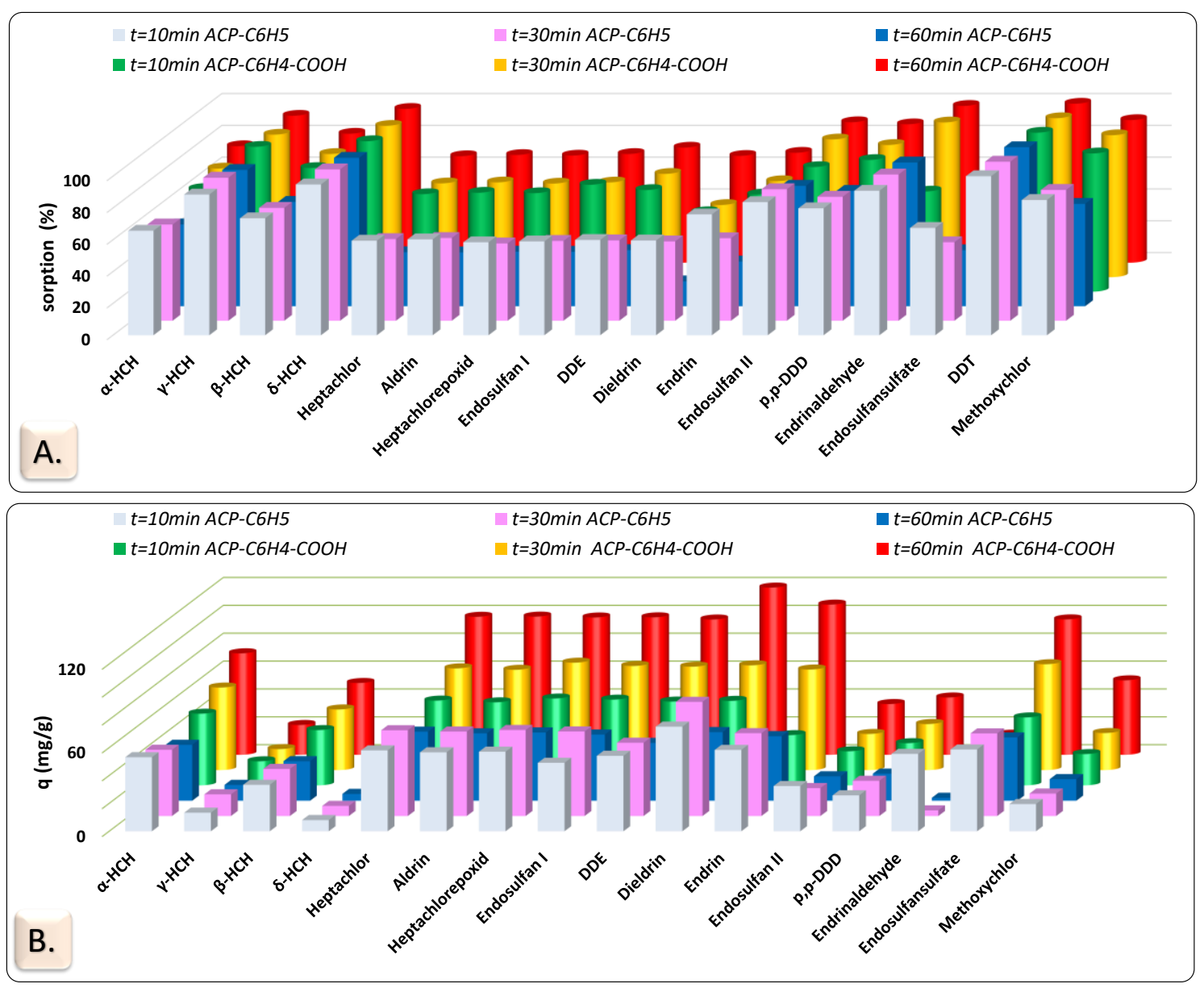

Fig. 5. Sorption percentage (A.) and capacity (B.) of the corresponding pesticides (sorption times: 10, 30 and $60 \mathrm{~min}$ ) from a hexane solution onto $\boldsymbol{A C P}-\mathrm{C}_{6} \mathrm{H}_{5}$ and $\boldsymbol{A C P}-\mathrm{C}_{6} \mathrm{H}_{5}-\mathrm{COOH}$ modified activated carbon. Sorbent mass $=5 \mathrm{mg}$. 
The sorption percentage and capacity, in aqueous solution extracted with hexane, of ACP, $\boldsymbol{A} \boldsymbol{C P}-\mathrm{C}_{6} \mathrm{H}_{5}$ and $\boldsymbol{A C P}-\mathrm{C}_{6} \mathrm{H}_{4} \mathrm{COOH}$ of the studied pesticides are presented in Figure 4. Figure 4 indicates that heptachlor, aldrin, heptachlor epoxide, endosulfan I, dieldrin, endrin and endosulfan sulfate (Figure 4) are strongly trapped by $\boldsymbol{A C P}-\mathrm{C}_{6} \mathrm{H}_{4}$ $\mathrm{COOH}$ and $\boldsymbol{A C P}-\mathrm{C}_{6} \mathrm{H}_{5}$ by comparison with $\mathrm{ACP}$, while the difference is small for $\delta-\mathrm{HCH}, \mathrm{p}, \mathrm{p}-\mathrm{DDD}$, endrin aldehyde, DDT and methoxychlor. In hexane solution, Figure 5 shows that the high sorption values of organochlorine pesticides on modified ACP $\left(\boldsymbol{A C P}-\mathrm{C}_{6} \mathrm{H}_{5}\right.$ and $\left.\boldsymbol{A C P}-\mathrm{C}_{6} \mathrm{H}_{5}-\mathrm{COOH}\right)$ is obtained at a relatively short contact time. These materials are able to adsorb a remarkable amount (90$126 \mathrm{mg} \mathrm{g}^{-1}$ ) of pesticide are adsorbed by $\boldsymbol{A C P}$ $\mathrm{C}_{6} \mathrm{H}_{5}$ and $\boldsymbol{A} \boldsymbol{C P}-\mathrm{C}_{6} \mathrm{H}_{5}-\mathrm{COOH}$ in the case of heptachlor, aldrin, heptachlorepoxide, endosulfan I, DDE, DieldrinEndrin, endosulfan II, and endosulfan sulfate; however the values are much lower for $\delta$ - $\mathrm{HCH}$ and eldrin $(\leq 10 \%)$.

These differences between the sorption percentages of the different pesticides can shed some light on the structures and interactions involved in the trapping process. We will discuss the differences on the typical examples of heptachlor on one side and $\alpha-\mathrm{HCH}$ and DDT on the other side. For heptachlor, the sorption capacity increases from $35 \%$ on ACP to $95 \%$ on $\boldsymbol{A C P}-\mathrm{C}_{6} \mathrm{H}_{5}$ and $91 \%$ on $\boldsymbol{A C P}-\mathrm{C}_{6} \mathrm{H}_{5}-\mathrm{COOH}$; while for $\alpha-\mathrm{HCH}$ and DDT it only increases from 94 to $98 \%$. As stated above, ACP is a porous material [26, 28], the sorption of pesticides and other molecules in ACP relies on the porosity [26] (pore size distribution). The different interactions involved in the sorption of organic molecules are London forces, hydrophobic but also specific chemical interactions, such as the presence of basic and carbonyl groups, and $\pi-\pi$ interactions [32]. For $\boldsymbol{A} \boldsymbol{C P}-\mathrm{C}_{6} \mathrm{H}_{5}$, only $\pi-\pi$ stacking and hydrophobic interactions (the average water contact angle of the basal surface of HOPG is $\sim 82^{\circ}$ [33]) should be observed. In a neutral medium, $\boldsymbol{A C P}$ $\mathrm{C}_{6} \mathrm{H}_{4}-\mathrm{COOH}$ is deprotonated to $\boldsymbol{A C P}-\mathrm{C}_{6} \mathrm{H}_{4}-\mathrm{COO}^{-}$ (the $\mathrm{pK}$ is 2.8-3.0) [19]. As the experiments in Figure 4 were performed in water $\mathrm{C}=\mathrm{O}---\mathrm{Cl}$ [34] and $\pi-\pi$ interactions can be expected for $\boldsymbol{A C P}$ $\mathrm{C}_{6} \mathrm{H}_{4}-\mathrm{COO}^{-}$, but not hydrophobic interactions as $\boldsymbol{C}-\mathrm{C}_{6} \mathrm{H}_{4}-\mathrm{COOH}$ : is rather hydrophilic with water contact angles from $\sim 15-20^{\circ}$ at $\mathrm{pH}$ 6-7 [35]. As concerns the pesticides in this work, all of them are lipophilic (they have a low solubility $(S)$ in water [34] and high octanol/water partition coefficients $\left(\log K_{\text {ow }}\right)[36,37]$. For example, for the compounds of Figure 5: heptachlor $S=0.07 \mathrm{mg} \mathrm{l}^{-1}$ and $\log K_{\text {ow }}$ $=5.27-6.06 ; \delta-\mathrm{HCH} S=0.01 \mathrm{mg} \mathrm{l}^{-1}$ and $\log K_{\text {ow }}$ $\sim 4.8$; DDT $S=0.01 \mathrm{mg} \mathrm{l}^{-1}$ and $\log K_{\text {ow }}=6.38-$ 6.91). Therefore, the sorption differences observed between heptachlor and $\alpha-\mathrm{HCH}$, DDT should have another origin than hydrophobic (as $\boldsymbol{A C P}-\mathrm{C}_{6} \mathrm{H}_{4}-$ $\mathrm{COO}^{-}$is hydrophilic) or $\pi-\pi$ interactions (both $\boldsymbol{A C P}-\mathrm{C}_{6} \mathrm{H}_{5}$ and $\boldsymbol{A C P}-\mathrm{C}_{6} \mathrm{H}_{4}-\mathrm{COO}^{-}$are aromatic oligomers).

Figure 6 shows the structure of typical pesticides: heptachlor is the simplest of the polychlorinated bicylooctane structures (which also include aldrin, heptachlor epoxide, endosulfan I, dieldrin, endrin and endosulfan sulfate).

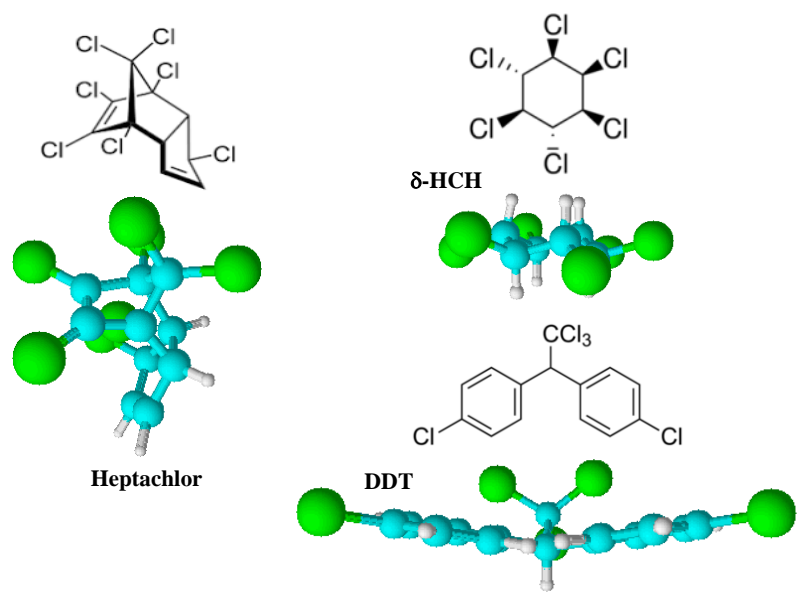

Fig. 6. Structures of heptachlor, $\delta-\mathrm{HCH}$ and DDT

For these compounds, molecular models show a volume of chlorine atoms. While $\delta-\mathrm{HCH}$ and DDT are polychlorinated cyclohexane and aromatic structures for which all the chlorine atoms are close from the equator plane and in the plane, respectively. The nearly flat polychloromolecules, such as $\delta$-HCH and DDT, interact strongly with ACP within its pores, the sorption would much lower for molecules, such as heptacholor for which chlorine atoms are dispersed in a volume. In contrast the three molecules would interact strongly with the aromatic groups in the lamellar structure of and through $\mathrm{C}=\mathrm{O}---\mathrm{Cl}$, in $\mathrm{ACP}-$ $\mathrm{C}_{6} \mathrm{H}_{4}-\mathrm{COO}^{-}$. The differences between ACP on one side and $\boldsymbol{A C P}-\mathrm{C}_{6} \mathrm{H}_{5}$ and $\boldsymbol{A C P}-\mathrm{C}_{6} \mathrm{H}_{4}-\mathrm{COO}^{-}$on the other side would therefore be related to steric effects.

If we now compare the performance of the two grafted layer $\boldsymbol{A} \boldsymbol{C P}-\mathrm{C}_{6} \mathrm{H}_{5}$ and $\boldsymbol{A} \boldsymbol{C P}-\mathrm{C}_{6} \mathrm{H}_{4}-$ $\mathrm{COOH}$ in hexane solution (Fig. 5 , sorption time $\mathrm{t}=$ $60 \mathrm{~min}$ ) using the equation below (Equation 3):

$$
\begin{gathered}
\uparrow \mathrm{C}-\mathrm{Ph}-\mathrm{COOH}(\%)= \\
=\frac{{ }^{\mathrm{C}}-\mathrm{C} 6 \mathrm{H} 4-\mathrm{COOH}-\%_{\mathrm{C}-\mathrm{C} 6 \mathrm{H} 5}}{\%_{\mathrm{C}}-\mathrm{C} 6 \mathrm{H} 4-\mathrm{COOH}} * 100
\end{gathered}
$$


we observe that grafting carboxyphenyl layers onto ACP $\left(A C P-\mathrm{C}_{6} \mathrm{H}_{4}-\mathrm{COOH}\right.$ as they carboxylic groups should be protonated in hexane) enhances the sorption ability of this material. The increased sorption percentage from $\boldsymbol{A C P}-\mathrm{C}_{6} \mathrm{H}_{5}$ to $\boldsymbol{A C P}-\mathrm{C}_{6} \mathrm{H}_{4}-\mathrm{COOH}$, is up to: $76 \%$ for dieldrin, $60 \%$ for endrin, $\approx 50 \%$ for: endosulfan sulfate, heptachlorepoxid, endosulfan I, heptachlor, aldrin but only 15-30 \% for: endosulfan II, p,p-DDD, $\beta-\mathrm{HCH}$, methoxychlor and $\alpha-\mathrm{HCH}$ and $\sim 0 \%$ for DDT. This enhanced trapping with in the presence of carboxylic groups has already been observed during the sorption of chlordecone, a polychlorinated pesticide, on ACP with different $\mathrm{COOH}$ contents [38] but also in molecularly imprinted polymers (MIPs) [39]. In this final investigation, the binding between heptachlor, DDT and polymethylmethacrylate was modelled by DFT methods and electrostatic interactions were shown to be responsible for the efficiency of the MIP. The enhanced trapping of heptachlor and $\boldsymbol{A C P}-\mathrm{C}_{6} \mathrm{H}_{4}-\mathrm{COOH}$ can be assigned to the same interactions but also to the formation of $-\mathrm{Cl}---$ $\mathrm{O}=\mathrm{C}(\mathrm{OH})-[34]$ and hydrogen bonds [40] between the chlorinated pesticides and the carboxylic group; such bonds have been observed in biological molecules [41] and crystals. Therefore, the preferred interaction with $A C P-\mathrm{C}_{6} \mathrm{H}_{4}-\mathrm{COOH}$ by reference to $A C P-\mathrm{C}_{6} \mathrm{H}_{5}$ should be related to the presence of carboxylic groups. However, for $\delta-\mathrm{HCH}$ and DDT, the interactions are of the same order in $A C P-\mathrm{C}_{6} \mathrm{H}_{5}$ and $A C P-\mathrm{C}_{6} \mathrm{H}_{5}-\mathrm{COOH}$, in this case also steric effects should contribute.

Finally, one finds increased interaction in the order ACP $<A C P-\mathrm{C}_{6} \mathrm{H}_{5}<A C P-\mathrm{C}_{6} \mathrm{H}-\mathrm{COOH}$ for heptachlor, but the interactions are similar for $\delta$ $\mathrm{HCH}$ and DDT on the three sorbents.

\section{CONCLUSIONS}

The removal of organochlorine pesticides through the sorption process is an interesting way to dispose of these toxic molecules. We show that a significant increase in ACP performance can be achieved by controlling the interfacial properties of the sorbent by the covalent surface attachment of polyphenylene films. This modification is easily achieved (60 $\mathrm{nm}$ in an ultrasonic bath) by dediazonation of diazonium salts, leading to radicals that react with the carbon surface. We show that changing the bonded $-\mathrm{C}_{6} \mathrm{H}_{5}$ group to $-\mathrm{C}_{6} \mathrm{H}_{5}-\mathrm{COOH}$ drastically improves the sorption efficiency of some of these modified ACPs. Moreover, this change is specific to the structure of the pesticide through steric effects. A large choice of readily available aromatic substituted amines permits to vary the functional groups $(-\mathrm{OH},-$ halides, $-\mathrm{CN},-\mathrm{SH},-\mathrm{COOH},-\mathrm{CHO}$, $-\mathrm{C}=\mathrm{O}$ and so on) $[15,16]$. These amines are readily transformed "in situ" to the corresponding diazonium salts, which permits tailoring of the surface properties of the sorbents, thereby opening a whole window of opportunities for possible selective adsorption of chemical species onto these sorbent surfaces. The results obtained in this study indicate that in aqueous solution, the sorption is favoured by $\mathrm{O}---$ $\mathrm{Cl}$ bonding between the pesticide and the film attached to the sorbent. Therefore, among the various possibilities mentioned above, films with high hydrogen bonding capacities should be favoured, such as aromatic groups with several $\mathrm{COOH}$ or $\mathrm{NH}_{2}$ groups. We are presently investigating such routes.

Acknowledgements. No funding to declare.

\section{REFERENCES}

[1] G. Matthews, Pesticides: Health, Safety and the Environment, John Wiley \& Sons, 2008. DOI:10.1002/0470865687

[2] Y. Li et al., Sources and pathways of selected organochlorine pesticides to the Arctic and the effect of pathway divergence on $\mathrm{HCH}$ trends in biota: A review, Science of the Total Environment, 342, 87-106 (2005). https://doi.org/10.1016/j.scitotenv.2004.12.027

[3] M. El-Shahawi et al., An overview on the accumulation, distribution, transformations, toxicity and analytical methods for the monitoring of persistent organic pollutants, Talanta, 80, 1587-1597 (2010). DOI:10.1016/j.talanta.2009.09.055

[4] T. Ahmad et al., Removal of pesticides from water and wastewater by different adsorbents: A review, Journal of Environmental Science and Health, Part C 28, 231-271 (2010). https://doi.org/10.1080/10590501.2010.525782

[5] R. Betarbet et al., Chronic systemic pesticide exposure reproduces features of Parkinson's disease, Nature Neuroscience, 3, 1301-1306 (2000). DOI:10.1038/81834

[6] S. Mostafalou et al., Pesticides and human chronic diseases: evidences, mechanisms and perspectives, Toxicology and Applied Pharmacology, 268, 157-177 (2013). DOI:10.1016/j.taap.2013.01.025

[7] M. Fontcuberta et al., Chlorinated organic pesticides in marketed food: Barcelona, 2001-06, Science of the Total Environment, 389, 52-57 (2008). DOI: $10.1016 /$ j.scitotenv.2007.08.043

[8] D. H. Garabrant et al., DDT and related compounds and risk of pancreatic cancer, Journal of the National Cancer Institute, 84, 764-77 (1992).

https://doi.org/10.1093/jnci/84.10.764

[9] M. Rodrigo et al., Electrochemically assisted remediation of pesticides in soils and water: A review, Chemical Reviews, 114, 8720-8745 (2014). DOI: $10.1021 / \mathrm{cr} 500077 \mathrm{e}$

[10] T. M. Phillips et al., Biodegradation of hexachlorocyclohexane $(\mathrm{HCH})$ by microorganisms, Biodegradation, 16, 363-392 (2005). 
DOI: $10.1007 / \mathrm{s} 10532-004-2413-6$

[11] P. Abhilash et al., Remediation of lindane by Jatropha curcas L.: utilization of multipurpose species for rhizoremediation, Biomass and Bioenergy, 51, 189-193 (2013). DOI: 10.1016/j.biombioe.2013.01.028

[12] G. Kyriakopoulos et al., Adsorption of pesticides on carbonaceous and polymeric materials from aqueous solutions: a review, Separation \& Purification Reviews 35, 97-191 (2006). https://doi.org/10.1080/15422110600822733

[13] M. Delamar et al., Covalent modification of carbon surfaces by grafting of functionalized aryl radicals produced from electrochemical reduction of diazonium salts, Journal of the American Chemical Society, 114, 5883-5884 (1992). DOI: 10.1021/ja00040a074

[14] A. Berisha et al., Electrode surface modification using diazonium salts, Electroanalytical Chemistry, CRC Press, 2015, pp.115-224. DOI: 10.1201/b19196-4

[15] M. M. Chehimi, Aryl Diazonium Salts: New Coupling Agents and Surface Science, John Wiley \& Sons, 2012.

[16] D. Bélanger et al., Electrografting: a powerful method for surface modification, Chemical Society Reviews, 40, 3995-4048 (2011). DOI:10.1039/C0CS00149J

[17] A. Berisha et al., Physisorption vs. grafting of aryldiazonium salts onto iron: A corrosion study, Electrochimica Acta, 56, 10762-10766 (2011). DOI: 10.1016/j.electacta.2011.01.049

[18] A. Berisha et al., Grafting of an aluminium surface with organic layers, RSC Advances, 6, 78369-78377 (2016). DOI: 10.1039/C6RA15313E

[19] C. Saby et al., Electrochemical modification of glassy carbon electrode using aromatic diazonium salts. 1. Blocking effect of 4-nitrophenyl and 4-carboxyphenyl groups, Langmuir, 13, 6805-6813 (1997). DOI: $10.1021 / \mathrm{la} 9610330$

[20] M. Busson, et al., Photochemical grafting of diazonium salts on metals, Chemical Communications, 47, 1263112633 (2011). DOI: 10.1039/C1CC16241A

[21] C. Mangeney et al., Electroless ultrasonic functionalization of diamond nanoparticles using aryl diazonium salts, Diamond and Related Materials, 17, 1881-1887 (2008). DOI:10.1016/j.diamond.2008.04.003

[22] F. Mirkhalaf, et al., Frequency effects on the surface coverage of nitrophenyl films ultrasonically grafted onto indium tin oxide, Langmuir, 27, 1853-1858 (2011). DOI: $10.1021 / \mathrm{la} 104402 \mathrm{z}$

[23] J.-P. Jasmin et al., Straightforward grafting approach for cyclam-functionalized screen-printed electrodes for selective $\mathrm{Cu}$ (II) determination, Electrochimica Acta, 200, 115-122 (2016). DOI:10.1016/j.electacta.2016.03.141

[24] C. Cannizzo et al., Calix [6] arene mono-diazonium salt synthesis and covalent immobilization onto glassy carbon electrodes, Tetrahedron Letters, 55, 4315-4318 (2014). DOI: 10.1016/j.tetlet.2014.06.043

[25] J.-P. Jasmin et al., Fabrication and characterization of all-covalent nanocomposite functionalized screenprinted voltammetric sensors, Electrochimica Acta, 133, 467-474 (2014). DOI:10.1016/j.electacta.2014.04.069

[26] P. A. Gauden et al., Estimating the pore size distribution of activated carbons from adsorption data of different adsorbates by various methods, Journal of Colloid and Interface Science, 273, 39-63 (2004).
DOI:10.1016/j.jcis.2003.08.033

[27] E. Coulon et al., Electrochemical attachment of organic groups to carbon felt surfaces, Langmuir, 17, 7102-7106 (2001). DOI: $10.1021 / \mathrm{la0} 010486 \mathrm{c}$

[28] M. Gineys et al., Grafting of activated carbon cloths for selective adsorption, Applied Surface Science, 370, 522 527 (2016). DOI: 10.1016/j.apsusc.2015.11.257

[29] A. Elyacoubi et al., Development of an amperometric enzymatic biosensor based on gold modified magnetic nanoporous microparticles, Electroanalysis, 18, 345350 (2006). https://doi.org/10.1002/elan.200503418

[30] B. Jin, et al., Multi-residue detection of pesticides in juice and fruit wine: A review of extraction and detection methods, Food Research International, 46, 399-409 (2012). DOI: 10.1016/j.foodres.2011.12.003

[31] G. Socrates, Infrared and Raman Characteristic Group Frequencies: Tables and Charts, John Wiley \& Sons, 2004. https://doi.org/10.1002/jrs.1238

[32] A. P. Terzyk, Adsorption of biologically active compounds from aqueous solutions on to commercial unmodified activated carbons. Part V. The mechanism of the physical and chemical adsorption of phenol, Adsorption Science \& Technology, 21, 539-585 (2003). https://doi.org/10.1260/0263617041514910

[33] Y. Wei et al., Intrinsic wettability of graphitic carbon, Carbon, 87, 10-17(2015). DOI:10.1016/j.carbon.2015.02.019

[34] P. Auffinger et al., Halogen bonds in biological molecules, Proceedings of the National Academy of Sciences of the United States of America, 101, 1678916794 (2004). DOI: 10.1073/pnas.0407607101

[35] D. M. Packwood et al., pH-dependent wettability of carboxyphenyl films grafted to glassy carbon, Australian Journal of Chemistry, 64, 122-126 (2011). https://doi.org/10.1071/CH10285

[36] A. Noble, Partition coefficients (n-octanol-water) for pesticides, Journal of Chromatography, A 642, 3-14 (1993). DOI: 10.1016/0021-9673(93)80072-G

[37] A. Paschke et al., Concentration dependence of the octanol/water partition coefficients of the hexachlorocyclohexane isomers at $25 \mathrm{C}$, Chemical Engineering \& Technology, 23, 666-670 (2000). https://doi.org/10.1002/1521-4125(200008)23:8<666:: AID-CEAT666>3.0.CO;2-5

[38] A. Durimel et al., $\mathrm{pH}$ dependence of chlordecone adsorption on activated carbons and role of adsorbent physico-chemical properties, Chemical Engineering Journal, 229, 239-249 (2013). DOI:10.1016/j.cej.2013.03.036

[39] K. Singh et al., Computational and experimental studies of molecularly imprinted polymers for organochlorine pesticides heptachlor and DDT, Current Analytical Chemistry, 8, 562-568 (2012). DOI: $10.2174 / 157341112803216807$

[40] C. B. Aakeröy et al., The C-H・• Cl hydrogen bond: does it exist?, New Journal of Chemistry, 23, 145-152 (1999). DOI:10.1039/A809309A

[41] J. P. Lommerse et al., The nature and geometry of intermolecular interactions between halogens and oxygen or nitrogen, Journal of the American Chemical Society, 118, 3108-3116 (1996). DOI:10.1021/ja953281x 
